\title{
Anticipated Barrier to Health Seeking Behavior dan Sosial Ekonomi pada Penyintas Kanker
}

\section{SIFA FITRI*}

Departemen Psikologi Kepribadian dan Sosial, Fakultas Psikologi Universitas Airlangga

\begin{abstract}
ABSTRAK
Setiap tahun terjadi lonjakan prevalensi penyintas kanker di Indonesia. Angka kematian di Indonesia yang disebabkan oleh kanker mencapai angka 132,6 penderita kanker dalam populasi 100.000 orang pada tahun 2018. Keterlambatan diagnosis menjadi salah satu faktor yang mempengaruhi naiknya angka kematian karena kanker. Status sosial dan ekonomi adalah salah satu faktor yang mungkin berperan pada keputusan penyintas kanker untuk tidak memeriksakan diri. Penelitian ini bertujuan untuk membandingkan dan melihat apakah ada perbedaan respon kelompok-kelompok sosial ekonomi pada anticipated barrier to visit general practitioner. Penelitian ini menggunakan metode pengisian kuesioner Awareness and Belief about Cancer pada 101 penyintas kanker. Ditemukan tidak adanya perbedaan respon antara kelompok-kelompok sosial dan ekonomi pada anticipated barrier to visit general practitioner. Sebagian besar dari responden menilai bahwa ketakutan akan diagnosis dokter adalah hal yang membuat responden mempertimbangkan keputusannya untuk pergi ke dokter.
\end{abstract}

Kata kunci: kanker, penyintas kanker, perilaku sehat, sosial dan ekonomi

\begin{abstract}
Every year, cases of cancer in Indonesia are getting higher and higher. The death rate which caused by cancer in Indonesia is reaching 132,6 patients in every 100.000 population at 2018. Lateness of diagnoses are one of the cause of the plummeted death rate of cancer. Social and economic position are one of the factors that might to some degree, explain the barrier to not visit general practitioner. This research used online questionnaire, Awareness and Belief about Cancer with 101 randomly sampled cancer patient. The research result show that there is no difference of mean in social and economic position for anticipation barrier to visit general practitioner respond. Respondent agree that worry about doctor might found are often make them to delay their doctor visit or even not attended it.
\end{abstract}

Keywords: cancer, cancer patient, health seeking behavior, social and economic

Buletin Penelitian Psikologi dan Kesehatan Mental (BRPKM), 2021, Vol. 1(1), 172-182,

*Alamat korespondensi: Fakultas Psikologi Universitas Airlangga, Kampus B Universitas Airlangga Jalan

Airlangga 4-6 Surabaya 60286. Surel: sifa.fitri-2016@unair.ac.id

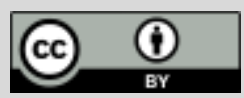

Naskah ini merupakan naskah dengan akses terbuka dibawah ketentuan the Creative Common Attribution License (CC-BY-4.0) (http://creativecommons.org/licenses/by/4.0), sehingga penggunaan, distribusi, reproduksi dalam media apapun atas artikel ini tidak dibatasi, selama sumber aslinya disitir dengan baik. 


\section{PEN D A H U L U A N}

World Health Organization (WHO) menyatakan kanker adalah penyebab kematian tertinggi kedua di dunia. Data statistik kanker dunia menyatakan pada tahun 2018, terdapat kurang lebih 18,1 juta kasus baru. Pada tahun yang sama pula, angka kematian di dunia yang disebabkan oleh kanker mencapai 9.6 juta jiwa. Dari data yang sama, didapatkan informasi bahwa dari 6 kasus kematian di tahun 2018, salah satu penyebabnya adalah penyakit kanker (IARC Global Cancer Observatory, 2018)

Survei kesehatan yang diadakan Riskedas tahun 2019 silam, Indonesia terus mengalami lonjakan prevalensi penyintas penyakit tidak menular (Kementrian Kesehatan Republik Indonesia, 2019). Badan Kesehatan Dunia (WHO) memaparkan jumlah kasus penyakit kanker di Indonesia pada tahun 2018 mencapai 348,807 jiwa dengan jumlah kematian 207,210 jiwa (World Health Organization, 2020)

Kanker, baik angka kematian atau penderita, terus meningkat dikarenakan usia penduduk, terjadinya pertumbuhan populasi dan semakin tingginya perilaku pemicu kanker terutama pada negara-negara berkembang (Jemal et al., 2011). Salah satu faktor yang mempengaruhi angka penderita kanker dan kematian yang disebabkan oleh kanker adalah rendahnya angka kunjungan ke ahli medis untuk memeriksakan dirinya saat sudah merasakan gejala. Diketahui bahwa $65 \%$ penyintas kanker di Indonesia memeriksakan dirinya pada ahli medis (dokter, dokter spesialis) dan mendapati diri mereka sudah mengidap kanker stadium lanjut (Meilanova, 2019).

Amat disayangkan karena penyakit kanker dapat diobati dengan kemungkinan harapan hidup yang lebih besar apabila penyintas mendapatkan pengobatan yang tepat saat stadium awal. Persentase angka harapan hidup ini berkurang drastis saat penyintas kanker baru melakukan perawatan saat kanker yang didertia sudah mencapai stadium lanjut. Penyintas kanker serviks hanya memiliki harapan hidup 15\%, penyintas kanker payudara dan kanker usus hanya 6\% sementara penyintas kanker kulit pada stadium lanjut hanya memiliki angka harapan hidup sebesar 17\% (Pranita, 2020).

Penelitan-penelitian sebelumnya menemukan adanya hubungan yang signifikan antara mengunjungi praktisi kesehatan dan kegiatan screening dengan pengetahuan, jarak tempat pemeriksaan, dukungan petugas kesehatan, rasa tidak nyaman, serta halangan dan kepercayaan mengenai kanker (Engeland et al., 1998; Lagerlund et al., 200; Coleman et al., 2011; Romadani, 2014). Penelitian yang berfokus pada keterlambatan perawatan pada subjek penyintas penyakit kanker mulut di India ini membuahkan kesimpulan bahwa akses pada fasilitas kesehatan, perilaku sehat, serta status ekonomi mempengaruhi individu untuk segera memeriksakan dirinya pada praktisi kesehatan (Agarwal, Sethi, Sareen, \& Dhingra, 2011)

Di Indonesia, pemerintah telah mencoba untuk memberikan bantuan-bantuan asuransi nasional seperti JKN-KIS dan BPJS untuk mengeliminasi disparitas ekonomi yang membuat masyarakat sulit mengakses layanan kesehatan. Meskipun begitu, dalam realitanya, asuransi kesehatan nasional ini masih dianggap kurang cukup membantu. Tidak sedikit yang mengeluh soal sistem BPJS yang membuat penyintas kanker di Indonesia terpaksa menunggu lebih dalam perawatannya. Belum lagi rujukan pengobatan kanker yang masih terfokus pada satu rumah sakit tertentu (RS Dharmais) membuat penyintas kanker di Indonesia harus mengeluarkan biaya lebih untuk penginapan dan persiapan perawatan lainnya (Wicaksono, 2018).

Indonesia adalah negara dengan tingkat kompleksitas yang tinggi. Setiap daerah di Indonesia memiliki perbedaan ras, etnik, ekonomi, geografis, budaya juga politik yang berbeda-beda. Hal ini memungkinkan adanya respon yang berbeda dari satu daerah dengan daerah yang lain dalam penelitian ini. 
Data statistik milik Badan Pusat Statistik (BPS) menjelaskan telah terjadinya penurunan angka kemiskinan nasional secara bertahap, nyatanya kesenjangan sosial dan ekonomi masih terjadi di Indonesia. Hal ini dikarenakan adanya perbedaan definisi antara garis kemiskinan yang digunakan oleh Indonesia dan Bank Dunia. Indonesia mendefinisikan garis kemiskinan di Indonesia dengan pendapatan perkapita hanya Rp354.386,00,- (bernilai sekitar USD \$25) per bulannya. Sementara Bank Dunia menggunakan klasifikasi bahwa mereka yang hidup dibawah garis kemiskinan memiliki penghasilan kurang USD \$1.23 perhari. Dua klasifikasi yang berbeda ini menimbulkan kesenjangan antara data milik Indonesia dan dunia. Pada klasifikasi milik Bank Dunia, dapat dikatakan bahwa sebagian besar penduduk di Indonesia berada dibawah batas garis kemiskinan (Indonesia Investment, 2017)

Dalam segi demografis, terdapat perbedaan mencolok antar individu yang tinggal di pusat kota akan lebih mudah mendapatkan akses fasilitas kesehatan dibandingkan dengan pinggir kota atau desa. Pembangunan nasional yang sebelumnya berpusat di Pulau Jawa dan Sumatera lebih mudah mendapatkan akses ke fasilitas kesehatan dibandingkan dengan individu yang tinggal di Pulau Kalimantan atau Sulawesi (Himawan \& Hapsari, 2017)

Terdapat disparitas ekonomi, pendidikan, dan perbedaan sosial-geografis yang dapat mempengaruhi bagaimana individu mendapatkan akses fasilitas kesehatan. Aspek-aspek ini dapat menjadi faktor lain yang membuat individu tidak memeriksakan dirinya pada praktisi kesehatan atau fasilitas kesehatan (Kaplan, Haan, Syme, Minkler, \& Winkleby, 1987)

Perilaku sehat (Health-seeking behavior) adalah sebuah perbuatan yang dilakukan oleh individu untuk mencapai sehat; kesejahteraan secara jiwa, raga, dan sosial (Poortaghi, Raiesifar, Bozorgzad, Golzari, \& Parvizy, 2015). Perilaku sehat ini bisa terjadi dengan atau tanpa masalah kesehatan dan dalam lingkup potensial masalah kesehatan (Chinn, 1999)

Ide dasar dari teori health belief model adalah mengkonsepsi health belief atau kepercayaan kesehatan yang mempengaruhi perilaku sehat individu atau kelompok (Norman \& Conner, 2017). Asumsi bahwa belief mempengaruhi perilaku individu telah ajukan oleh Lewin (1951) dalam konsep 'valence'; dimana kepercayaan mengenai sesuatu membuat sebuah perilaku menjadi menarik atau tidak menarik (Abraham \& Sheeran, 2015)

Perceived barrier terjadi ketika individu sampai pada kesimpulan bahwa perilaku yang hendak atau sudah mereka lakukan itu tidak memiliki keuntungan apapun, membuang-buang waktu, tidak menyenangkan (menyakitkan, sulit, dan sebagainya), mahal, ataupun berbahaya (Janz \& Becker, 1984). Anticipation barrier to visit general practitioner adalah salah satu bentuk dari perceived barrier yang mungkin terjadi. Penelitian milik Simon (2010) mengatakan bahwa semakin banyak halangan yang dirasa oleh individu akan membuat individu tersebut menunda pemeriksaan ke dokter meskipun sudah merasakan gejala yang cukup berbahaya (Simon, Waller, Robb, \& Wardle, 2010).

SES: resourced based adalah sebuah pengukuran status sosial ekonomi berdasarkan sumber daya yang dimiliki oleh individu (Diemer \& Rasheed Ali, 2009). Sumber daya tersebut terdiri dari beberapa determinan yaitu: a. Pendidikan yang dicapai, b. Pendapatan keluarga, c. Pendapatan individu, d. Kekayaan (aset)

Dari penelitian ini penulis membuat hipotesis bahwa apakah terdapat perbedaan respon yang signifikan dari kelompok-kelompok sosial ekonomi terhadap anticipated barrier to visit general practitioner. Batasan dalam penelitian ini mencakup Anticipated Barrier to Visit General Practitioner, didefinisikan sebagai halangan yang membuat individu enggan untuk memeriksakan diri mereka pada praktisi kesehatan atau pergi ke rumah sakit (Hvidberg, Wulff, Pedersen, \& Vedsted, 2015), menggunakan 
definisi status sosial dan ekonomi berdasarkan resource yang dimiliki individu yaitu pendidikan dan pendapatan, ditujukan untuk penyintas kanker berusia minimal atau diatas 18 tahun, partisipan bertempat tinggal di Indonesia. Tujuan dalam penelitian ini adalah untuk mengetahui apakah ada perbedaan antar kelompok sosial dan ekonomi untuk memeriksakan diri mereka pada praktisi kesehatan saat mereka merasakan tanda-tanda penyakit kanker dengan memperhatikan konteks sosialekonomi pada masyarakat Indonesia.

\section{Desain Penelitian}

\section{E T O D E}

Penelitian ini menggunakan penelitian kuantitatif bersifat non-eksperimental yaitu survei. Penelitian kuantitatif bersifat non-eksperimental ini dilakukan dengan mengambil data dari banyak responden yang dihadapkan dengan pertanyaan yang sama (Neuman, 2007).

\section{Partisipan}

Menggunakan alat ukur ABC dan metode survei, peneliti menyebarkan tautan dari kuesioner daring yang sebelumnya disiapkan. Kuesioner daring dipersiapkan dengan halaman informed consent sesuai dengan kaidah penelitian. Informed consent dirasa butuh mengingat partisipan yang hendak didapatkan adalah penyintas kanker, dimana partisipan penelitian ini dapat dikategorikan sebagai sesuatu yang sensitif. Tautan tersebut disebarkan melalui media sosial seperti twitter, facebook, WA, dan lainnya. Dikarenakan penelitian ini meneliti isu yang cukup sensitif, maka peneliti berinisiatif untuk mengajukan permintaan pengambilan data pada Cancer Information and Support Center; komunitas yang didirikan untuk para penyintas kanker Indonesia dengan harapan penyintas kanker yang terlibat dalam komunitas itu dapat berbagi sedikit mengenai pengalamannya.

Kriteria partisipan dalam penelitian ini yaitu merupakan penyintas kanker yang berusia 18 tahun atau lebih. Kriteria ini diberikan untuk mempersempit populasi demi mendapatkan data yang lebih koheren dengan variabel status sosial ekonomi. Mengacu pada konvensi dari International Labour Organization (ILO) yang dipatuhi oleh Indonesia, batas usia minimum untuk mendapatkan pekerjaan adalah 18 tahun. Sementara menurut hukum di Indonesia sendiri, batas usia minimum untuk bekerja adalah 15 tahun, dimana pada usia tersebut, pekerja masih dianggap sebagai pekerja anak yang tidak boleh membahayakan kesehatan, keselamatan, atau moral orang muda. Dengan pertimbangan batas usia minimum untuk bekerja tersebut serta variabel yang hendak digunakan adalah pendapatan, diambillah batas usia subjek minimal berusia 18 tahun atau lebih dari 18 tahun.

Demografis responden berdasarkan pendidikan dalam penelitian ini didominasi oleh penyintas kanker yang memiliki pendidikan terakhir strata satu dan diikuti oleh responden dengan pendidikan terakhir Sekolah Menengah Atas (SMA). Hal ini membuat data pendidikan akan sulit untuk dibandingkan karena tidak tersebarnya data secara luas untuk mencangkup semua golongan sehingga menyebabkan ketimpangan sampel untuk representasi kelompok-kelompok pendidikan formal yang lain. Sementara itu, ketimpangan juga terjadi pada kelompok pendapatan. Kelompok pendapatan dengan rata-rata pendapatan Rp 3.000.000 - Rp 4.800.000 per bulan menjadi satu-satunya kelompok pendapatan dengan responden di bawah 10.

\section{Data Deskriptif}

Dalam penelitian ini data penyintas kanker yang memenuhi kriteria sampel penelitian adalah sebanyak 98 orang. Dari 98 orang yang merupakan penyintas kanker ini, terdapat data-data yang ternyata tidak lolos uji asumsi normalitas. Sehingga sampel-sampel yang bersifat outlier dihilangkan agar data bersifat 
normal. Setelah menghapus sebanyak 18 data outlier, diperoleh data normal yang mencangkup 80 penyintas kanker. Uji statistik deskriptif menunjukkan bahwa variabel anticipated barrier to visit general practitioner memiliki nilai minimum 7, nilai maksimum 16, dengan mean sebesar 10,92 dan standar deviasi 1,868. Sementara itu, variabel pendidikan memiliki nilai minimum 1, nilai maksimum 4, dengan mean 1,95 dan standar deviasi 0,810 . Variabel pendapatan memiliki nilai minimum 1 , nilai maksimal 5, mean 3,26, dan standar deviasi 1,589.

Pengukuran

\section{Variabel Pendidikan}

Berdasarkan penggolongan yang dibuat oleh BPS (Badan Pusat Statistik), pendidikan di Indonesia dibagi menjadi dua yaitu formal dan non-formal. Dalam penelitian ini, penggolongan pendidikan digolongkan berdasarkan tingkatan pendidikan formal terakhir yang telah diterima individu. Karenanya, pendidikan dalam penelitian ini dikategorikan sebagai berikut:

1. SMA/Sederajat, golongan pendidikan formal terendah dalam penelitian ini. Telah menyelesaikan wajib sekolah duabelas tahun.

2. S1/Strata satu, golongan pendidikan formal yang ditempuh setelah SMA. Memiliki gelar Sarjana.

3. S2/strata dua, golongan pendidikan formal yang ditempuh setelah strata satu. Memiliki gelar Magister.

4. S3/strata tiga, golongan pendidikan formal yang ditempuh setelah strata dua. Memiliki gelar Doktor.

\section{Variabel Pendapatan}

Berdasarkan penggolongan yang dibuat oleh BPS (Badan Pusat Statistik), pendapatan penduduk di Indonesia dikategorikan sebagai berikut :

1. Golongan pendapatan sangat rendah adalah jika pendapatan rata-rata kurang dari $\mathrm{Rp}$ 1.800.000 per bulan.

2. Golongan pendapatan rendah adalah jika pendapatan rata-rata antara $\mathrm{Rp} 1.800 .000-\mathrm{Rp}$ 3.000.000 per bulan.

3. Golongan pendapatan menengah adalah jika pendapatan rata-rata antara $\mathrm{Rp} 3.000 .000-\mathrm{Rp}$ 4.800.000 per bulan.

4. Golongan pendapatan tinggi adalah jika pendapatan rata-rata antara Rp 4.800.000 - Rp 7.200.000 per bulan.

5. Golongan pendapatan sangat tinggi adalah jika pendapatan rata-rata lebih dari Rp 7.200.000 per bulan.

\section{Variabel Anticipatied Barrier to Visit General Practitioner}

Pada penelitian ini, untuk mengukur tingkat anticipated barrier to visit general practitioner alat ukur Awareness and Belief about Cancer (ABC) digunakan sebagai tolak ukur. Alat ukur Awareness and Belief about Cancer dikembangkan berdasarkan penelitian milik Simon (2010) sebagai dasar dari alat ukur. Alat ukur ini digunakan sebagai tolak ukur dengan skala likert 1 hingga 5 (1 untuk 'sangat setuju', 2 untuk 'setuju', 3 untuk 'tidak yakin atau netral', 4 untuk 'tidak setuju', dan 5 untuk 'sangat tidak setuju') dengan 4 aitem yang mewakilkan anticipated barrier to visit general practitioner.

Pada penelitian ini penulis melakukan uji asumsi yaitu uji normalitas dengan menggunakan SPSS 25.0 for Windows. yang bertujuan untuk melihat apakah data yang dimiliki terdistribusi secara normal atau 
tidak. Normalitas data dapat dari variabel dependen per kelompok Data yang dimiliki dapat dikatakan persebarannya normal jika taraf signifikansinya $\mathrm{p}>0,05$. Dalam penelitian ini nilai masing-masing signifikansi untuk uji normalitas data diperoleh untuk uji normalitas data Alat Ukur Anticipated Barrier to Visit General Practitioner dengan Pendidikan mempunyai nilai signifikansi 'SMA=0,285' , 'S1=0,081' '' S2=0,547' dan 'S3=0,976'. Setelah di analisis dapat disimpulkan bahwa data tersebut terdistribusi normal pada kelompok pendidikan. Pada uji normalitas data Alat Ukur Anticipated Barrier to Visit General Practitioner dengan Pendapatan nilai masing-masing signifikansi 'Pendapatan rata-rata kurang dari Rp 1.800.000 per bulan=0,204' , 'Pendapatan rata-rata antara Rp 1.800 .000 - Rp 3.000.000 per bulan= 0,066','Pendapatan rata-rata antara Rp 3.000.000 - Rp 4.800.000 per bulan= 0,849',' Pendapatan rata-rata antara Rp 4.800.000 - Rp 7.200.000 per bulan=0,394', 'Pendapatan rata-rata lebih dari $\mathrm{Rp}$ 7.200.000 per bulan=0,235'. Setelah di analisis dapat disimpulkan bahwa data tersebut terdistribusi normal pada kelompok pendapatan.

\section{HAS I L P E N EL I T IA N}

\section{Uji Hipotesis - Uji Komparasi}

Uji komparasi yang dilakukan adalah uji komparatif ANOVA. Uji ini dipilih karena penggolongan sample yang lebih dari dua kelompok dan data telah memenuhi asumsi-asumsi yang diperlukan untuk melakukan uji ANOVA. Uji ini dilakukan untuk membandingkan apakah ada perbedaan dalam respon kelompok-kelompok status sosial dan ekonomi terhadap anticipated barrier to visit general practitioner. ANOVA adalah sebuah tes yang bersifat omnibus, yaitu sebuah tes untuk mengecek hipotesis nol atau tidak ada perbedaan antara kelompok tanpa memberikan informasi perbandingan kelompok, maka dilakukan tes post-hoc Tukey untuk melihat perbedaan rata-rata antara kelompok.

Hasil dari uji komparasi yang dilakukan menunjukkan bahwa nilai signifikansi pendapatan dengan anticipated barrier to visit general practitioner sebesar $\mathrm{p}=0,270$, variabel uji dikatakan memiliki perbedaan statistik yang signifikan apabila nilai signifikansi atau $\mathrm{p}<$ nilai kritis $(0,05)$. Dapat disimpulkan disini, dari uji komparasi yang diperkuat oleh uji lanjut, bahwa bahwa tidak ada perbedaan respon antar kelompok pendapatan terhadap anticipated barrier to visit general practitioner. $(\mathrm{a}=95 \%)$

Hasil dari uji komparasi yang dilakukan menunjukkan bahwa nilai signifikansi pendidikan dengan anticipated barrier to visit general practitioner sebesar $\mathrm{p}=0,437$, variabel uji dikatakan memiliki perbedaan statistik yang signifikan apabila nilai signifikansi atau $\mathrm{p}<$ nilai kritis $(0,05)$. Hasil post-hoc yang sudah dilakukan, tidak ditemukan adanya angka signifikansi yang dapat memenuhi asumsi adanya perbedaan yang signifikan antar kelompok $(\mathrm{p}<0,05)$.

Melihat hasil dari uji komparasi dan uji lanjut (post-hoc) disimpulkan disini bahwa tidak ada perbedaan respon antar kelompok pendidikan terhadap anticipated barrier to visit general practitioner. (a=95\%)

\section{I S K U S I}

Seperti halnya negara-negara dengan pendapatan bawah dan menengah, tingginya angka kematian penderita kanker dikarenakan keterlambatan penanganan yang diakibatkan oleh penundaan diagnosis juga perawatan. Penundaan inilah membuat angka harapan hidup penyintas kanker di seluruh dunia, terutama Indonesia, menjadi lebih rendah (Jemal et al., 2011)

Keputusan untuk menunda memeriksakan diri pada dokter adalah sebuah fenomena yang terjadi tidak hanya pada penderita kanker. Penundaan terjadi sebagai hasil manifestasi, sebuah usaha untuk 
meminimalisir kecemasan dan mengatasi stress dalam bentuk menolak untuk mengakui diagnosis tersebut atau denial (Cousins, 1982). Terjadinya penundaan pemeriksaan diri ke dokter ini nyatanya terjadi sangat sering, salah satunya dengan angka frekuensi satu dari tiga dari wanita yang menyadari bahwa dirinya terkena kanker payudara, akan menunda pemeriksaan ke dokter (Facione \& Facione, 2006).

Faktor-faktor yang berperan dalam penundaan pemeriksaan penyintas kanker pun, tidak jauh berbeda dari kebanyakan penyakit. Salah satunya adalah faktor sosial, ekonomi, dan kultural. Dari akses ke pusat kesehatan, kebiasaan dan gaya hidup, kurangnya pengetahuan, pendapatan, rasa malu, bahkan ketakutan akan kemoterapi (Facione \& Facione, 2006).

Berdasarkan hasil uji komparasi yang telah dilakukan, didapati bahwa tidak ada perbedaan respon anticipated barrier to visit general practitioner secara signifikan berdasarkan kelompok-kelompok status sosial dan ekonomi. Hal ini ditunjukkan dengan hasil dari uji komparasi kelompok pendapatan ataupun pendidikan dengan anticipated barrier to visit general practitioner memiliki nilai signifikansi 0,270 dan 0,473 . Dimana tidak ditemukan adanya perbedaan respon terhadap anticipated barrier to visit general practitioner baik dari subjek dengan pendidikan terakhir mereka di tingkat sekolah menengah atas, strata satu, strata dua, serta strata tiga.

Hal ini konsisten dengan penelitian Llewellyn dan kawan-kawan (2004) yang menjelaskan bahwa pendidikan hanya berperan terhadap penundaan pemeriksaan pada individu-individu dengan pendidikan di bawah SMA. Dijelaskan bahwa individu-individu dengan pendidikan tidak lanjut (di bawah SMA) akan miliki resiko lebih tinggi untuk menunda pemeriksaan.

Dalton (2008), Shack (2007), Gorey (2009), serta Kogevinas (1997) dan Woods (2006) menyatakan bahwa dalam studi mereka ditemukannya ketimpangan sosial ekonomi pada penyintas kanker (Rachet, et al., 2010). Dan Hvidberg (2011) memaparkan bahwa dalam penelitiannya, tidak ditemukan hubungan yang benar-benar jelas antara status sosial dan ekonomi dan halangan untuk mencari pengobatan secara general.

Dari uji komparasi yang dilakukan juga didapati bahwa tidak ada perbedaan respon anticipated barrier to visit general practitioner dari tingkatan pendapatan. Subjek dengan pendapatan di bawah rata-rata, subjek dengan pendapatan menengah, ataupun subjek dengan pendapatan di atas rata-rata.

Dalam penelitian ini, lebih dari setengah responden tidak setuju dengan pernyataan "Saya terlalu malu untuk berkunjung ke dokter." Hanya terdapat dua responden yang menyatakan mereka setuju bahwa mereka merasakan malu untuk berkunjung ke dokter dan menganggap itu sebagai sebuah halangan. Selebihnya tidak memiliki pendapat negatif atau positif (netral) mengenai pernyataan tersebut.

Serupa dengan pernyataan sebelumnya, pernyataan "Saya khawatir akan membuang-buang waktu dokter" hanya dianggap sebagai sebuah halangan untuk memeriksakan diri ke dokter oleh 3 responden. Sementara itu lebih dari setengah jumlah responden memberikan respon negatif terhadap pernyataan ini. Total 40 responden menjawab "Tidak Setuju" dan 1 responden menjawab "Sangat Tidak Setuju" terhadap pernyataan ini.

Dalam penelitian, dapat dikatakan bahwa rasa malu dan kekhawatiran untuk membuang-buang waktu dokter tidak dianggap sebagai sebuah halangan yang membuat penyintas kanker mengurungkan niat untuk pergi memeriksakan dirinya. Hal ini dapat ditimbulkan oleh berbagai faktor, salah satunya adalah dengan fakta bahwa individu mengeluarkan sumber daya, baik waktu dan materil, untuk membayar waktu serta keahlian dokter tersebut untuk pemeriksaan. Dijabarkan pula bahwa interaksi positif dengan praktisi kesehatan (dokter, suster) dapat mempengaruhi perilaku sehat dengan melegitimasi 
perilaku tersebut. Sementara itu, responden yang menjawab aitem tersebut sebagai sebuah halangan untuk memeriksakan dirinya biasanya mendekripsikan gejala-gejala yang dia rasakan adalah sesuatu yang sepele dan tidak membutuhkan perhatian dokter. Hubungan yang tidak begitu dekat dengan praktisi kesehatan yang dikunjungi pula dapat membuat individu merasakan bahwa dia membuangbuang waktu dokter untuk memeriksa gejalanya yang sepele (Cromme, Whitaker, Winstanley, Renzi, \& Smith, 2016)

Pernyataan "Saya khawatir dengan kemungkinan temuan dokter saat pemeriksaan" dianggap sebagai sebuah halangan untuk memeriksakan diri ke dokter oleh 39 orang yang terdiri dari 14 respon yang menyatakan "Setuju" dan 25 orang responden yang menyatakan "Sangat setuju". Hal serupa juga ditemukan oleh Hvidberg (2011), dimana dalam penelitiannya, satu dari empat responden menjawab bahwa mereka akan menunda pemeriksaan ke dokter meskipun gejala yang mereka alami bisa saja menjadi serius.

Pernyataan "Saya khawatir dengan kemungkinan temuan dokter saat pemeriksaan" secara general dapat dianggap sebagai sebuah halangan yang membuat penyintas kanker memutuskan untuk tidak mengunjungi dokter. Hal ini dikarenakan rasa takut dan cemas muncul sebagai pedang bermata dua, baik menjadi motivasi ataupun penghalang untuk pergi ke memeriksakan diri. Individu yang memeriksakan dirinya, menggunakan rasa takut dan cemas untuk memotivasi diri untuk pergi memeriksakan diri. Sehingga ketika dia mendapatkan diagnosis dari gejala-gejala yang dia rasakan, ketidakpastian yang menyebabkan kecemasan itu hilang. Sementara itu, individu yang menunda untuk memeriksakan dirinya menjelaskan rasa takut akan diagnosis, kecemasan, dan juga kesedihan itu membuatnya menunda pemeriksaan untuk mengetahui diagnosis dari gejala yang dia rasakan (Facione \& Facione, 2006)

Sementara itu, pernyataan "Saya tidak dapat meluangkan waktu ke dokter." dianggap sebagai sebuah halangan oleh 14 responden. Kebanyakan dari responden yang menganggap pernyataan ini sebagai sebuah halangan berasal dari mereka yang memiliki pendidikan akhir strata satu.

Besar kemungkinan responden menganggap hal ini sebagai sebuah halangan hanya memiliki pekerjaan aktifnya sebagai sumber pendapatan mereka. Mereka akan merasa bahwa jika mereka absen dari pekerjaan mereka, pendapatan mereka juga akan terpotong dan tentunya harus mengeluarkan dana untuk pemeriksaan. Hal ini mungkin diakibatkan akibat kompleksitas waktu yang dihabiskan untuk bekerja bagi mereka yang merupakan pekerja aktif (Llewellyn, Johnson, \& Warnakulasuriya, 2004). Dimana mereka kesulitan untuk mengambil waktu untuk memeriksakan dirinya karena padatnya pekerjaan yang mereka miliki.

King dan Leach (1950) dalam penelitian mereka yang tidak menemukan hubungan antara penundaan dengan pendapatan. Tetapi dalam penelitian tersebut ditemukan bahwa individu yang hanya memiliki pekerjaannya sebagai satu-satunya alat untuk pendapatan, asset atau sumber daya, akan menunda lebih sering dibandingkan dengan mereka yang yang memiliki asset atau sumber daya lain (KING \& LEACH, 1950)

Dalam penelitian ini, kebanyakan dari responden memiliki pendapatan diatas rata-rata masyarakat Indonesia. Hal ini bisa saja diakibatkan karena adanya disparitas ekonomi antara penyintas sehingga penyintas yang pendapatannya di bawah rata-rata tidak dapat bertahan hidup. Pengobatan kanker, baik itu skrining ataupun kemoterapi dan obat-obatan memiliki harga yang cukup menguras kantung. Terlebih lagi jika pengobatan dijalani tanpa asuransi kesehatan, baik nasional ataupun tidak. Sejalan dengan penelitian sebelumnya yang menyatakan meskipun telah diberikan asuransi kesehatan, angka harapan hidup penyintas kanker golongan sosial dan ekonomi bawah masih lebih rendah daripada 
mereka yang berada di golongan sosial dan ekonomi menengah ke atas (Abdelsattar, Hendren, \& Wong, 2017).

Dalam jurnal milik Facione (2006) salah satu argument atau alasan yang paling sering dilontarkan oleh responden yang menunda pemeriksaan dalam penelitian tersebut adalah biaya yang harus dikeluarkan untuk pengobatan. Baik kemoterapi ataupun pemeriksaan lanjutan. Hal ini juga menjelaskan hasil penelitian Llewellyn dan kawan-kawan (2004) mengenai kompleksitas pekerjaan dan pendapatan yang menjadi salah satu faktor penundaan pemeriksaan.

Realitanya, meskipun masyarakat dengan golongan sosial dan ekonomi menengah ke bawah di Indonesia sudah sangat terbantu dengan adanya asuransi kesehatan nasional, tidak dapat dipungkiri dengan infrastruktur yang masih belum menjangkau seluruh wilayah geografis Indonesia juga membuat penyintas kanker berpikir dua kali untuk melakukan pengobatan. Saat ini di Indonesia sendiri hanya terdapat tiga rumah sakit rujukan khusus kanker dimana hanya ada satu rumah sakit rujukan milik negara (RS Dharmais). Dua rumah sakit khusus kanker di Indonesia dimiliki oleh swasta (RS Siloam, RS Fuda). Ketiga rumah sakit tersebut terletak di Ibu kota negara, Jakarta. Sesuai dengan pernyataan Facione dan Llewellyn sebelumnya, dengan kondisi infrastruktur kesehatan yang jauh dari tempat tinggal mereka, banyak penyintas kanker memutuskan untuk menunda pemeriksaan mereka karena biaya yang harus mereka keluarkan. Demikian pula bisa jadi karena aspek inilah, kebanyakan dari responden penelitian ini berasal dari golongan ekonomi sosial menengah keatas, dimana responden dalam penelitian ini kemungkinan besar memiliki dana lebih untuk memeriksakan diri dan melakukan pengobatan secara mandiri.

Llewellyn dan kawan-kawan (2004) menyatakan bahwa pendapatan yang rendah dan pendidikan yang kurang merupakan faktor yang konsisten sebagai prediktor dalam penundaan pemeriksaan. Namun pada penelitian ini, tidak ditemukan adanya perbedaan yang signifikan dari respon kelompok-kelompok status sosial dan ekonomi terhadap anticipated barrier to visit general practitioner. Hal ini dapat terjadi dikarenakan oleh beberapa alasan, seperti ukuran sampel yang kecil dan kurang representatif terhadap kelompok-kelompok status sosial dan ekonomi ataupun kesalahan-kesalahan lainnya.

\section{S I M P U L A N}

Berdasarkan hasil uji analisis data dari penelitian ini dapat disimpulkan bahwa tidak ada perbedaan respon yang signifikan dari kelompok-kelompok sosial ekonomi terhadap anticipated barrier to visit general practitioner. Dengan prevalensi kanker di Indonesia yang semakin meningkat, pemerintah harus segera membangun lebih banyak lagi infrastruktur untuk mendukung pengobatan dan perawatan penyakit kanker. Diperlukan lebih dari satu rumah sakit nasional yang benar-benar dikhususkan untuk merujuk penyintas kanker. Saat ini, di Indonesia hanya terdapat tiga rumah sakit khusus kanker dan dua di antaranya milik swasta.

\section{U CAPAN TERIMAKASIH}

Ucapan terima kasih disampaikan kepada Cancer Support and Information Center yang telah bersedia membantu dalam menyebarkan kuesioner penelitian juga pada pihak-pihak lain yang telah berperan dalam penelitian ini. 


\section{DEKLARASI POTENSI TERJADINYAKONFLIK KEPENTINGAN}

Sifa Fitri tidak bekerja, menjadi konsultan, memiliki saham, atau menerima dana dari perusahaan atau organisasi manapun yang mungkin akan mengambil untung dari diterbitkannya naskah ini.

\section{PUSTAKA ACUAN}

Abdelsattar, Z. M., Hendren, S., \& Wong, S. L. (2017). The impact of health insurance on cancer care in disadvantaged communities. Cancer, 123(7), 1219-1227. https://doi.org/10.1002/cncr.30431

Abraham, C., \& Sheeran, P. (2015). The Health Belief Model (Vol. 2).

Agarwal, A. K., Sethi, A., Sareen, D., \& Dhingra, S. (2011). Treatment delay in oral and oropharyngeal cancer in our population: the role of socio-economic factors and health-seeking behaviour. Indian Journal of Otolaryngology and Head and Neck Surgery: Official Publication of the Association of Otolaryngologists of India, 63(2), 145-150. https://doi.org/10.1007/s12070-011-0134-9

Chinn, P. . (1999). Theory and nursing: Integrated knowledge development. St. Louis: Mosby.

Cousins, N. (1982). Denial: Are Sharper Definitions Needed? JAMA, 248(2), 210-212. https://doi.org/10.1001/jama.1982.03330020054029

Cromme, S. K., Whitaker, K. L., Winstanley, K., Renzi, C., \& Smith, C. F. (2016). Worrying about wasting GP time as a barrier to, (July). https://doi.org/10.3399/bjgp16X685621

Diemer, M. A., \& Rasheed Ali, S. (2009). Integrating Social Class Into Vocational Psychology: Theory and Practice Implications. Journal of Career Assessment, 17(3), 247-265. https://doi.org/10.1177/1069072708330462

Facione, N. C., \& Facione, P. A. (2006). The cognitive structuring of patient delay in breast cancer. Social $\begin{array}{llll}\text { Science } \& \quad \text { Medicine, } & \text { 63(12), }\end{array}$ https://doi.org/https://doi.org/10.1016/j.socscimed.2006.08.014

Himawan, A., \& Hapsari, D. . (2017, December 19). Sri Mulyani Akui Pembangunan masih terpusat di Jawa dan Sumatera. Retrieved from suara.com: https://www.suara.com/bisnis/2017/12/19/172945/sri-mulyani-akui-pembangunan-masihterpusat-di-jawa-dan-sumatera?page=all

Hvidberg, L., Wulff, C. N., Pedersen, A. F., \& Vedsted, P. (2015). Barriers to healthcare seeking, beliefs about cancer and the role of socio-economic position. A Danish population-based study. Preventive Medicine, 71, 107-113. https://doi.org/https://doi.org/10.1016/j.ypmed.2014.12.007

Indonesian Investment. (2017, January 12). Kemiskinan di Indonesia.

Janz, N. K., \& Becker, M. H. (1984). The Health Belief Model: a decade later. Health Education Quarterly, 11(1), 1-47. https://doi.org/10.1177/109019818401100101

Jemal, A., Bray, F., Center, M. M., Ferlay, J., Ward, E., \& Forman, D. (2011). Global cancer statistics. CA: $A$

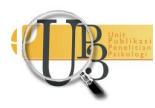


Cancer Journal for Clinicians, 61(2), 69-90. https://doi.org/https://doi.org/10.3322/caac.20107

Kaplan, G. A., Haan, M. N., Syme, S. L., Minkler, M., \& Winkleby, M. (1987). Kaplan GA, Socioeconomic Status and Health, 1987.pdf.

KING, R. A., \& LEACH, J. E. (1950). Factors contributing to delay by patients in seeking medical care. Cancer, 3(4), 571-579. https://doi.org/10.1002/1097-0142(1950)3:4\&lt;571::aidcncr2820030403\&gt;3.0.co;2-\#

Llewellyn, C. D., Johnson, N. W., \& Warnakulasuriya, S. (2004). Factors associated with delay in presentation among younger patients with oral cancer. Oral Surgery, Oral Medicine, Oral Pathology, $\begin{array}{llll}\text { Oral Radiology, and } & \text { 707-713. }\end{array}$ https://doi.org/https://doi.org/10.1016/j.tripleo.2004.01.007

Meilanova, D. R. (2019). Gara-gara Telat Berobat, Kematian Penderita Kanker di Indonesia Tinggi. Bisnis.Com. Retrieved from https://lifestyle.bisnis.com/read/20190117/106/879637/gara-garatelat-berobat-kematian-penderita-kanker-di-indonesia-tinggi

Neuman, W. . (2007). Basic of Social Research : Qualitative and Quantitative Approaches 2nd Edition. Boston: Pearson Education Inc.

Observatory, I. G. C. (2018). GLOBOCAN 2018 database.

Pranita, E. (2020, February 7). Deteksi Dini Tingkatkan Angka Harapan Hidup Pasien Kanker, Kok Bisa? Retrieved from kompas.com: https://sains.kompas.com/read/2020/02/07/090300023/deteksidini-tingkatkan-angka-harapan-hidup-pasien-kanker-kok-bisa-?page=all

Romadani, D. I. (2014). Gambaran Penderita Kanker Serviks Yang Terlambat Melakukan Deteksi Dini Kanker Serviks.

Simon, A. E., Waller, J., Robb, K., \& Wardle, J. (2010). Patient Delay in Presentation of Possible Cancer Symptoms: The Contribution of Knowledge and Attitudes in a Population Sample from the United Kingdom. Cancer Epidemiology Biomarkers \&amp;Amp; Prevention, 19(9), 2272 LP - 2277. https://doi.org/10.1158/1055-9965.EPI-10-0219

Wicaksono, B. S. (2018, October 10). Perih dan Perih, Menjadi Pasien Kanker yang Berobat dengan BPJS. World Health Organization. (2020). Cancer Country Profile.WHO 